\title{
THE ENVIRONMENTAL PROTECTION ORDINANCE: AN ADDITION TO THE MORASS OF LEGISLATION
}

\section{INTRODUCTION}

Canada's Arctic may be described as "sensitive". Some of the sensitive aspects of the Arctic's ecology are:

1. The permafrost is covered by a thin layer of tundra vegetation. Disruption of this protective layer exposes the permafrost to summer heat and starts an expanding process of melting and erosion.

2. The biological time scale is greatly expanded relative to that in moderate climates, therefore, the process of regeneration is extremely slow.

3. Pollution abatement by natural processes is also very slow. Wastes are preserved by the cold for long periods of time instead of decomposing rapidly as they do in the South.

4. The indigenous fauna is in a state of delicate balance. Dramatic fluctuations in population can occur when natural conditions vary slightly. the balance in this system can be greatly influenced by people and by changes in technology.

5. An important feature of the Arctic ecosystem is paucity of species. Southern ecosystems have numerous species, whereas those in the Arctic have very few. This lack of diversity makes the system vulnerable to disruption. Whereas in complex systems a single species can be eliminated without a major impact on the system, the loss of a single species in the Arctic could be much more serious. ${ }^{1}$

The foregoing points suggest the raison d'être of environmental legislation for the Arctic. To assess the rationale of the newly enacted Environmental Protection Ordinance ${ }^{2}$ (for ease of reference called the "Ordinance"), passed in the 1973, third session of the Northwest Territories Council and assented to on October 19,1973, one must look to the legislation dealing with environmental protection of Canada's Arctic existing at that time. Land use legislation, ${ }^{3}$ applicable to large-scale resource exploration and development, was promulgated pursuant to recent amendments to the Territorial Lands Act. ${ }^{4}$ Called the Territorial Lands Use Regulations (for ease of reference called the "Regulations"), the legislation provides for the creation of land management zones and the setting up of a land use operation permit system.

C. B. Armstrong of the Department of Indian Affairs and Northern Development takes the position that, "The Northern Land Use Regulations are the main instrument of environment management in Northern Canada."5 It is respectfully suggested this is not the case and that the newly enacted Ordinance attempts to meet some of the environment management deficiencies in the "Regulations".

2. ENVIRONMENT MANAGEMENT DEFICIENCIES IN THE "REGULATIONS" AS PARTIALLY REMEDIED $B Y$ THE ORDINANCE

(a) Restriction of the "Regulations" to the Western and High Arctic Pursuant to Section 3A of the Territorial Lands Act and Part II of the

\footnotetext{
1 Pollution Probe's Background Statement on the Arctic, March 28, 1972, revised April 12, 1972, at 12.

2 R.O. 1974, c. E-3.

* SOR/71-580, (1971) 105 Canada Gazette (Part II) 1908, November 24, 1971.

- R.S.C. 1970 c. T.6, amended by R.S.C. 1970 (1st Supp.) c. 48.

3 Armstrong, G. B., Report No. 307, delivered at the Fifth International Congress "Arctic Oil \& Gas: Problems \& Possibilities," held at Le Havre, France, May 2-5, 1973, at 10.
} 
"Regulations", four land management zones have been created in the Northwest Territories. Baffin Island and the Arctic region east of a line running north from Yellowknife to Coppermine, with the exception of an area along the Arctic Coast included within Zone 3, have been set apart and appropriated as land management zones. The "Regulations" do not apply to this area.

The "Regulations" were promulgated to control oil and gas exploration and development in the Arctic, Since such activity is carried on at present only in the Arctic Islands, the Mackenzie Delta and the Mackenzie Valley, there seemed to be no necessity for the "Regulations" to extend to the central and eastern Arctic. If and when large scale oil and gas exploration spreads to the Central and Eastern Arctic, the Governor-in-Council may set apart and appropriate additional Territorial lands as land management zones.

In contrast, by Section 3(1), the Ordinance applies to the whole of the Territories, including municipalities. This inclusion is important because some of the prime polluters in the Northwest Territories are located within municipalities. 6

(b) Restrictions of the "Regulations" to the Protection, Control and

Use of the Surface of Land in a Land Management Zone

Section 3B(a) of the Territorial Lands Act refers to "the protection, control and use of the surface land in a land management zone," but can it be assumed that oil and gas exploration involves only land surface disturbance?

Exploration undoubtedly has some effect on the wildlife habitat and may result in the disruption of traditional hunting and trapping patterns of the native population. The assumption that wildlife habitat protection flows from land surface protection may be erroneous. For example, shockwaves resulting from seismic testing in the Mackenzie Delta may be harmful to marine mammals such as the muskrat. Any reduction in the muskrat population could have repercussions for natives in the Mackenzie Delta region whose livelihood is linked to the muskrat population.

The "ordinance" defines "contaminant", "discharge" and "environment" and the definitions are wide-ranging:

2(b) "contaminant" means any solid, liquid, gas, odour, heat, sound, vibration or

combination of any of them the discharge of which into the environment may

(i) cause or contribute to the impairment of the quality of the environment, or

(ii) adversely affect the health, safety or comfort of any person;

2(c) "discharge" includes, but not so as to limit the meaning, any pumping, pouring, throwing, dumping, emitting, burning, spraying, spreading, leaking, spilling or escaping;

2(d) "environment" means the air, water (including ice and snow) and land of the Territories and all animal and plant life therein.

Unacceptable disruption of the muskrat population by seismic testing would seem to be caught by Section 6(1)(a) of the Ordinance:

No person shall discharge ... any contaminant into environment that causes or contributes or is likely to cause or contribute to substantial impairment of the quality of the environment; . . .

It is interesting to note that fish are not included within the definition of environment. Section 91(12) of the British North America Act ensures that sea coast and inland fisheries are within the legislative purview of the

'See discussion on Block Land Transfer under 2(d) and Council of the Northwest Territories Debates, 50th Session, Oct. 15-19, inclusive, 1973 , at 197 to 199 , and 218 . 
Parliament of Canada. Thus unacceptable disruption of the fish population is left to prosecutions under Section 33 of the Federal Fisheries Act.

(c) Restrictions of the "Regulations" to Large-Scale Land Use Operations

The "Regulations" are aimed at regulating only land use operations consistent with large-scale resource exploration and development:

2. In these "Regulations", ... .

'Land use operation' means any work or activity on territorial lands that involves one or more of the following.

(a) the use of more than 50 pounds of explosives in any one day or more than 300 pounds of explosives in any 30 day period,

(b) the use, except on a public road or trail, of any vehicle that exceeds 20,000 pounds net vehicle weight or the use of any vehicle of any weight that exerts pressure on the ground in excess of 5 pounds per square inch,

(c) the use of any self-propelled, power driven machine for moving earth or clearing land,

(d) the use of any stationary power driven machine for hydraulic prospecting, moving earth or clearing land,

(e) the use of any power driven machinery for earth drilling purposes, the operating weight of which exceeds 5,000 pounds, excluding the weight of drill rods or stems, bits, pumps and other ancillary equipment,

(f) the establishment of any campsite that is to be used in excess of 300 man-days,

(g) the levelling, grading, clearing or cutting of any line, trail or right-of-way exceeding five feet in width; ...

A person conducting a land use operation in a land management zone is required, pursuant to Section 17 of the "Regulations", to obtain a Land Use Permit authorizing that land use operation. ${ }^{7}$ In contrast, the Ordinance is aimed at regulating the behaviour and actions of individuals and small operators. $^{8}$

Section 6 of the Ordinance deals with the discharge of contaminants:

(1) No person shall discharge or permit the discharge of any contaminant into the environment that

(a) causes or contributes or is likely to cause or contribute to substantial impairment of the quality of the environment; or

(b) adversely affects or is likely to adversely affect the health, safety or comfort of any person.

(2) Notwithstanding Subsection (1) no offence is committed where the level of discharge of contaminants into the environment does not exceed the level of discharge that is established by regulation [made pursuant to this Ordinance].

Section 6 would seem to catch, for example, activities where unacceptable amounts of oil, fuel and chemicals are discharged into the environment and where improper disposal of human waste occurs. The latter is characterized by the "honey bag" phenomenon" (human waste stored in plastic disposable garbage bags for lack of sewage treatment systems in the small settlements of the Territories).

\section{Section 10 of the Ordinance deals with unsightly premises:}

No person shall permit premises owned, occupied or abandoned by him to be unsightly by permitting to remain, on any part of such premises,

(a) any unused dilapitated buildings,

(b) rubbish, or

(c) discarded materials, vehicles, machinery or equipment.

\footnotetext{
; For an example of operating conditions commonly attached to Land Use Permits, see Usher, Peter J., and Beakhurst, Grahame, Land Regulation in the Canadian North (Canadian Arctic Resources Committee, Ottawa, November, 1973).

- Council of the Northwest Territories Debates, 50th Session, October 15 to 19, inciusive, 1973, at 196.

"Id., at 199, concerning discussion of the "little green bags." How long is the Territorial Government to be immune from prosecution under Section 6 of the Ordinance? Yet note footnote 20.
} 
Empty fuel drums, abandoned because it is too costly to remove them, are familiar sights in the Territories around airports in the settlements. Presumably this situation would be caught by Section 10 .

In general, there seems to be little evidence to suggest that people activities caught by Sections 6 and 10 are any less damaging to the environment than land use operations as defined by the "Regulations". In fact, they may be more damaging. The large industrial "operator" with more money on hand for clean-up and for purchase and maintenance of sophisticated protective equipment may do less damage to the environment.

\section{EXEMPTIONS CONTAINED IN THE "REGULATIONS" AND IN THE ORDINANCE}

The exemption in the "Regulations" states:

\section{These "Regulations" do not apply to}

(a) anything done by a resident of the Yukon Territory or the Northwest Territories in the course of hunting, fishing or trapping; or

(b) lands, the surface rights to which have been disposed of by the Minister.

Sub-clause (b) has caused some confusion. Does land, the surface rights to which have been disposed of by the Minister of Indian Affairs and Northern Development exempt only lands where all surface rights have been disposed of, as for example, a mining lease granted under Section 44 of the Canada Mining Regulations? Or does the examption apply also to land where any surface rights have been disposed of? Do the "Regulations" apply to exploration licences and permits granted under the Canada Oil \& Gas Land Regulations where some surface rights are given to the licencees and permittees? This is a matter that must be resolved.

Sub-clause (b) exempts those Territorial lands in and around many municipalities in the Northwest Territories which have been transferred by the Governor-in-Council to the Commissioner of the Northwest Territories by Order-in-Council pursuant to Section 19 of the Territorial Lands Act. This transfer of Territorial lands, termed the "block transfer" system, gives to the Commissioner the control, management and administration of land blocks in the Northwest Territories. Under Section 4 of the Commissioner's Land Ordinance this Block land is sold to or leased by municipalities and the public from the Commissioner.

As of J anuary 1975, there were fourteen land blocks transferred by Orderin-Council to the Commissioner. They include: Yellowknife, Inuvik, RaeEdzo, Enterprise, Norman Wells, Fort Franklin, Fort Good Hope, Frobisher Bay, Fort Smith, Hay River, Fort Providence, Aklavik, Fort Simpson and Fort McPherson. There are approximately forty applications before the Territorial-Federal Lands Advisory Committee, made up of personnel from the Territorial Departments of Local Government and Economic Development and the Federal Department of Indian \& Northern Affairs, to transfer all the remaining communities in the Territories to the Commissioner for administration under the Commissioner's Land Ordinance.

It is important to note that $95 \%$ of the people living in the Territories reside within existing or proposed "block transfer" areas. Clearly, the Regulations do not catch those activities carried on within block transfer areas that cause unacceptable impairment of the environment. This is left to other legislation, principally the Environmental Protection Ordinance.

Sub-Clause (b) further exempts those Territorial lands leased or sold by the Minister of Indian Affairs \& Northern Development to 
Federal Government Departments and Federal Crown Corporations. ${ }^{10}$

The Ordinance, too, has its exemption; Section $3(2)$ of the Ordinance reads:

This Ordinance does not apply to any person who is authorized under an Act of the

Parliament of Canada or an Ordinance to do those things that, but for such Act or

Ordinance, are in contravention of this Ordinance or the regulations.

A list-by no means exhaustive-of the Acts or Ordinances that are contemplated by section 3(2) of the Ordinance is contained in Appendix "C".

\section{PROCEDURAL DEFICIENCIES IN THE "REGULATIONS"}

Under Section 20(1) of the "Regulations" the Engineer is required within 30 days of the receipt of an application for a land use permit either to issue the permit, reject it, or ask for further information. It is suggested that a thirty-day period is insufficient time to permit discussion with local persons and bodies (e.g. settlement council) interested in the proposed land use operation, especially since the information supplied to the Engineer when an application for a land use permit is made may be incomplete and may not be disseminated widely. Such interested persons should be encouraged to examine the proposal and should be given the time to put forward considered comments. ${ }^{11}$

Even if sufficient time is given to analyze the proposed land use operation, interested persons might need financial support to assist in obtaining professionals to analyze the probably sophisticated data contained in the application. The "Regulations" do not provide for this potential need. Yet if financial assistance were made available, most likely "the amount of misinformed controversy surrounding the [proposed land use operation] would be reduced substantially."12

The thirty-day period would not be so onerous if there were a requirement in the "Regulations" for the filing of an environmental impact study. Section 19(2) of the "Regulations" reads:

The Engineer may require an applicant for a land use permit to provide him with such information and data concerning the proposed use of land by the applicant as will enable the Engineer to evaluate any quantitative and qualitative effects of the proposed land use operation in the area in which the applicant proposes to use such land.

Much is left to the discretion of the Engineer. It follows that if the Engineer has a narrow view of his function and sees himself as a glorified filing clerk, then persons interested may be deprived of reports that would assist in assessing the proposed land use operation.

Pre-permit inspection to assist in the evaluation of permit applications as provided for in Sections 19 and 20 of the "Regulations" rarely has been ordered by the Engineer. The argument of the Department of Indian Affairs and Northern Development against mandatory pre-permit inspections is that this would slow down the process of application approval. ${ }^{13}$

A Land Use Advisory Committee having "no statutory existence in terms of either the Territorial Lands Act or its Regulations" exists as an

11. Viz., lands disposed of to the Ministry of Transport, the Royal Canadian Mounted Police, Northern Canada Power Commission, Department of Public Works, Department of National Health and Welfare, Department of the Environment, but not Canadian National Telecommunications or Northern Transportation Company Ltd.

1 See discussion in Land Regulation in the Canadian North, supra, n. 7, pp. 88-95.

12 Franson, R. T., and Burns, P. T., Environmental Rights for the Canadian Citizen: A Prescription for Reform (1974) 12 Alta. L. Rev, p. $153 \mathrm{ff}$.

1.. Supra, n. 7, at $77 \mathrm{ff}$. 
"administrative convenience" to assist in the assessment of land use applications. ${ }^{14}$ The Committee's effectiveness is a matter of conjecture. It has been suggested that it acts only in an advisory role and "all evidence suggests that the advice of some representatives on the Committee is largely ignored."15

\section{DISCUSSION OF THE ORDINANCE}

A good deal of controversy surrounded the enactment of the Ordinance. It is looked upon as being a "Provincial type" responsibility, consistent with the evolvement of Provincial status for the Northwest Territories. ${ }^{16}$

The Ordinance is administered by a Chief Environmental Protection Officer, at present Mr. Dan Billing who resides in Yellowknife. He is assisted in the performance of his duties by inspectors. Every inspector is a peace officer for the purpose of enforcing the provisions of the Ordinance.

Game Officers and Fire Safety Officers in the Northwest Territories have been designated inspectors under the Ordinance. It is open to the Chief Environmental Protection Officer to appoint Federal employees, such as Fisheries Officers, Forestry Officers and Land Use Inspectors, as inspectors, and this should be done. Members of the Territorial Department of Local Government resident in municipalities throughout the Northwest Territories should also be appointed as inspectors.

Because of the vast area of the Territories (one and one-third million square miles) and the extremely high cost of air transportation, a meagre budget for inspection-the present situation-could seriously hamper the enforcement of the Ordinance.

Public supervision is envisaged as the means to ensure inspection and enforcement difficulties are minimized. Local persons with knowledge of local conditions are encouraged to take a role in enforcement. R.C.M.P. personnel located throughout the Arctic and Municipal SecretaryManagers are such local persons. The Chief Environmental Protection Officer indicates that, in practice, once unacceptable impairment of the environment occurs, there is an almost automatic response by the local inhabitants and that response is communicated to inspectors charged with enforcement.

Because this is an Ordinance that deals with human behaviour it is odd that no large-scale public campaign followed the enactment of the Ordinance so as to ensure public awareness of its basic provisions. Presumably the money was not available.

At present, there is no training program for inspectors to ensure that they are kept abreast of current environmental information. Such a program should be instituted. Mr. Billing indicates that a manual to aid in enforcement is in preparation.

Ideally, a trouble shooter group of men properly trained and equipped to deal with the clean-up of unacceptable impairment of the environment should now be established. This is not the case, again presumably because of financial constraints.

Under Section 5, where the Chief Environmental Protection Officer is of the opinion, based on reasonable and probable grounds, that it is necessary or advisable for the protection of the environment to do so, he may by Order directed to any person require that person,

14 Id., at 77 .

is Id., at 82.

16 Council of the Northwest Territories Debates, 50th Session, October 15-19, inclusive, 1973, at 196, 204 and 207. 
(a) to install safeguards to prevent the discharge of contaminants into the environment;

(b) to site, transport or store any contaminant in the manner set out in the order; or

(c) to have on hand at all times such equipment and material necessary to alleviate the effect of any discharge of contaminants as may be specified in the order.

The question must be asked-"What resources does the Environmental Protection Officer have at his disposal to make an Order under Section 5?" There is no requirement in the Ordinance that an environmental impact statement be prepared to assist him in determining whether preventive measures should be taken. Must he only rely on the inspectors to provide the reasonable and probable grounds for the making of the Order? And if so, can he rely on his inspectors to provide them? Only through the prompt, efficient transmission of information from local inspectors in the field to the Chief Environmental Protection Officer in Yellowknife will he be aware of potential and actual breaches of the Ordinance in time to act effectively. Given the isolation and communication difficulties that characterize the Northwest Territories, this may be difficult.

The argument can be made that local inspectors should be given the power, exercisable on reasonable and probable grounds, that the Environmental Protection Officer has under section 5. But this should occur only if inspectors are properly trained.

Orders made under section 5 , Orders made under section 7 to stop or reduce the discharge of contaminants, and Orders made under section 8 to remedy or repair damage due to the discharge of contaminants, are to be brought to public attention through publication in local Territorial newspapers. As of May 1975 no orders have yet been made under these sections.

Section 5 contains no provision for the filing of a security deposit. The Environmental Protection Officer should have the power to demand a deposit where he deems it necessary. Under the Territorial Land Use Regulations, by section 26 , a security deposit may be included as a condition in the granting of a Land Use Permit. It is suggested that to rely only on section 8(3) of the Ordinance, which provides for the fixing of civil liability for clean-up upon the polluter, is not sufficient to insure that necessary preventive measures are taken. Some polluters have been known to flee the jurisdiction, making recovery of monies spent on clean-up difficult and time consuming.

Section 8(3) gives no right of action to human "victims." What of the Eskimo trapper of Banks Island whose annual catch of white fox is adversely affected by unacceptable impairment of the environment? Victims of certain crimes are compensated under Criminal Injuries Compensation legislation; victims of unacceptable environment impairment should also be compensated.

Section 10 , which has already been quoted, poses a dilemma for the Chief Environmental Protection Officer. He has the power under section 11 to notify the owner or occupier of unsightly premises that the condition must be corrected. Yet he is met with the argument that some abandoned buildings are old historical sites or are of archeological or historical importance, interest or significance, and thus protected by the relevant regulations promulgated under the Federal Northwest Territories Act, and by the Federal Historic Sites Monuments Act.

Section 11 states:

(1) When the Chief Environmental Protection Officer is satisfied that a condition 
mentioned in Section 10 exists, he shall so notify the owner or occupier of the premises or person who had abandoned the premises.

(2) A notice under Subsection (1) shall

(a) be in writing;

(b) be signed by the Chief Environmental Protection Officer;

(c) state that the condition mentioned in Section 10 exists;

(d) state what must be done to correct the condition;

(e) state the date before which the condition must be corrected, and

(f) be served by personal delivery thereof to the person to be notified or by sending such notice by registered mail addressed to the person at his latest known address, or where the person is a corporation, addressed to the registered office of the corporation in the Territories.

(3) Where a notice has been given under subsection (2) and the owner or occupier does not comply with the notice within the time allowed, the Chief Environmental Protection Officer may cause the premises of that owner or occupier to be cleaned up and the cost of carrying out such work is chargeable to the owner or occupier and becomes a debtdue to the Government of the Northwest Territories.

(4) An owner or occupier may within thirty days after receiving a notice under subsection (1), appeal the notice to the Supreme Court of the Territories.

(5) Where an appeal is made pursuant to subsection (1), the Court shall make such order as it in the circumstances deems just.

(6) An appeal that is made pursuant to subsection (3) operates as a stay of any proceedings that may be taken by the Chief Environmental Officer under this Ordinance against the person who made the appeal.

Section 11(4), (5) and (6) were added at the insistence of Councillor Genest and others who were concerned that the wide arbitrary powers given to the officer under section $11(3)$ should be subject to some control.17

As at the end of May, 1975, there have been no prosecutions brought under the offences and penalties section of the Ordinance. According to Mr. Billing, there have been a number of formal and informal requests to persons to remedy the unacceptable discharge of contaminants into the environment or to clean up unsightly premises. Mr. Billing indicates that such requests so far have been effective and prosecutions have not been necessary.

By section 14 it is sufficient proof of the offence to establish that it was committed by an employee or agent of the accused whether or not the employee or agent has been identified or has been prosecuted for the offence, unless the accused establishes that the offence was committed without his knowledge or consent and that he exercised all due diligence to prevent its commission. This is an important evidentary tool and will aid in enforcement.

Under section 15(1), prosecutions must be brought within three years of the time when the subject matter of the proceedings arose.

Under section 15(2), no proceedings in respect of an offence under the Ordinance may be instituted without the consent of the Territorial Director of Public Services. This subsection was added at the instance of Councillor Sibbeston: ${ }^{18}$

This is to prevent the possibility of persecution [sic] by environmentalists... .

\section{And Councillor Genest: 19}

It is inherent in any legislation such as this that the enforcement must be done with a fine hand and with good judgment but surely we can trust the Administration of these territories to use sound judgment. Nobody wants to close an industry that is providing 500 jobs or 100 jobs because it will not correct its pollution overnight.

1: Id., at 217, 251.

iv Id., at 253 .

19 Id., at 205. 
On the other hand, whether the consent of the Director will be easily obtained still remains open to question. This is especially important, given the comment of Councillor Searle: 20

I do not want the government in a position of enforcing it against me but then being the greatest polluter in the world and by not giving consent to prosecution against itself doing far worse damage to the environment.

Should the citizens' right of private prosecution be abrogated as it is by section 15(2)? Few statutes restrict the common law right of private prosecution by the necessary express language. ${ }^{21}$ If one accepts that citizen prosecutions serve as a very real stimulus for enforcement of legislation, it would seem that section $15(2)$ is undesirable.

To get around the fear of frivolous prosecutions, the Ordinance could have created a cause of action in a group who, by their interest and activity, demonstrated themselves to be adequate representatives of the public interest. ${ }^{22}$

When it is realized that the Ordinance is carefully drafted to protect the Chief Environmental Protection Officer and the Inspectors from judicial mandamus proceedings, by not creating an affirmative duty in the Officer to act, the suggestion of public interest representative prosecutions becomes more credible.

Under section 18 there is a provision for the making of regulations but as of January 1975 none have been promulgated.

\section{GENERAL COMMENT}

It has been suggested ${ }^{23}$ that environmental regulatory agencies display disturbing tendencies. Regulatory agencies can become "enmeshed in the bureaucratic web created by the particular system of administration." Acquiescence to vested interests can occur. An adoption of the biases of the industry and group of persons to be regulated may take place. Strong enforcement may not occur because of policy directives from the Minister or because of "inertia and fear of generating political heat."

The administrators of the Environmental Protection Ordinance most likely are susceptible to these tendencies to some degree. One way of working against such tendencies is to provide for public supervision of the administrators.

If the Chief Environmental Protection Officer and Inspectors fail to enforce the Ordinance vigorously, then there should be legislation to set up an Environmental Control Board which would be drawn from members of the public. The Board would review acts or omissions of the administrators and, if necessary, take steps to ensure the public's interest in maintaining a quality environment. This will indicate if and when such a Board is required in the Northwest Territories.

-GRAHAM PRICE*

\footnotetext{
20 Id., at 198-199.

21 Devlin, The Criminal Prosecution in England (London, 1960), at $R$. v. Schwerdt, 119 C.C.C. 81 (B.C.S.C.), per Wilson J., at 83, 88; R.v. Devereaux [1966] 2O.R. 290 at 293 (Ontario C.A.); Re Bokor and Justices of the Peace (1971) 4 C.C.C. (2d) 177, per Galligan J.

22 Lucas, A. R., Legal Techniques for Pollution Control: The Role of the Public (1971) 6 U.B.C. Law Rev. 167 at 185, 186.

2. Id., at 189.

*B.A., LL.B., Member of the Northwest Territories Bar.
} 